\title{
ON THE PHONETIC REALIZATION AND DISTRIBUTION OF COSTA RICAN RHOTICS
}

\author{
Luz Marina Vásquez Carranza
}

\begin{abstract}
RESUMEN
La muestra analizada del español producido por hablantes del Valle Central de Costa Rica evidencia que la vibrante múltiple ha sido substituida por una rótica asibilada, al tiempo que la vibrante simple también se asibila en tres contextos fonológicos: 1) en sílabas iniciales de más de una letra con la forma /tr/, 2) en posición intermedia en la palabra en sílabas iniciales complejas que aparecen después de una coronal sonora $/ 1 / \mathrm{o} / \mathrm{n} / \mathrm{y} 3$ ) en grupos de tipo $/ \mathrm{Cr} /$ en donde la rótica está en posición final, siempre presidiendo uno o más morfemas dependientes de clítico. La vibrante simple también evidencia asibilación al final de una frase. Se propone como posible explicación de tal asibilación de la vibrante múltiple la tendencia a nivel cros-lingüístico de reducir el proceso de articulación: en vez de enunciar la vibrante múltiple la cual requiere tensión controlada, precisa y sostenida del ápice de la lengua, se reduce la magnitud de movimiento en este lugar de articulación, resultando en una asibilación de la vibrante múltiple en todos los contextos. Por su parte, la asibilación de la vibrante simple se explica en términos de co-articulación.

Palabras clave: róticas, dialectos costarricenses, fonología, fonética, asibilación.
\end{abstract}

\begin{abstract}
The analysis of the Spanish data produced by speakers from the Costa Rican Central Valley evidenced that the trill has been substituted by an assibilated rhotic, while the tap also undergoes assibilation in three contexts: 1) in complex /tr/ onset clusters, 2) word-medially in complex onsets that come after a voiced coronal $/ 1 / \mathrm{or} / \mathrm{n} /$, and 3 ) in $/ \mathrm{rC} /$ clusters where the rhotic is in coda position, always before one or more bound clitic morphemes. Additionally, the tap assibilates phrase-finally. The proposal is that the assibilation of the trill results from the cross-linguistic tendency to reduce the articulation process: instead of producing the trill which requires controlled, precise, and sustained movement of the tongue tip, the magnitude of the movement of the tongue tip is reduced, resulting in assibilation of the trill in all contexts. Assibilation of the tap is explained in terms of coarticulation.
\end{abstract}

Key words: rhotics, Costa Rican dialects, phonology, phonetics, assibilation.

Luz Marina Vásquez Carranza. Ph.D. Applied Linguistics, Boston University. Actualmente, profesora de la Universidad de Costa Rica, Sede de Occidente.

Correo electrónico: luzmarinave@hotmail.com

Recepción: 14- 8- 2007

Aceptación: 13- 9- 2007 


\section{Introduction}

In contrast to most languages in the world that generally contain a single rhotic (Lipski 1990), Standard Spanish has two, namely a trill and a tap. These rhotics contrast only intervocalically; word-initially and word-finally, they are either in free variation or are neutralized. The tap and the trill have quite different phonetic realizations: whereas the former requires that the tongue move up to contact the roof of the mouth at the alveolar ridge and then move back to the floor of the mouth with a closure that has extra-short duration (Ladefoged 2001: 150), the latter consists of a series of brief occlusions made by the tip of the tongue against the alveolar ridge while the vibrating vocal cords sustain voicing; it requires tensed, controlled, precise, gesture (Bradley 2002; Ladefoged 2001; Recasens 1991). The latter segment is not among the typologically most common sounds in the world's languages (Widdison 1998), although it represents a highly salient feature of the Spanish phonological inventory. In fact, Widisson (1999) and Jiménez (1967) posit that the trill is one of the last speech sounds acquired by native speakers of Spanish, and although most non-native speakers can recognize it, few reach native-like pronunciation of this segment.

Whereas the tap is found in all Spanish dialects, outside of Northern Spain and in conservative Spanish communities, the trill has undergone great adjustments resulting in completely different phonetic realizations. Several researchers have looked at such dialectal variation and they report that some regions in Guatemala, Argentina, Cuba, Chile, Colombia, Panamá, Ecuador, Paraguay, Bolivia, Perú, Mexico, the United States, Spain (from Logroño to Zaragoza), and Costa Rica have an assibilated rhotic, that is, an alveolar tap or trill that is phonetically realized as a strident fricative [̌r] (Bradley 1998; Lipski 1994; Quilis 1999; Widdison 1998). Other dialects such as the ones spoken in Cuba, Puerto Rico, Panama, Mexico, and coastal Colombia and Venezuela have a velarized rhotic (Canfield 1962; Quilis 1999; Widdison 1998).

Dialectal variation has been ascribed to different factors, including contact with other languages such as Native American languages, French and African languages, and English (Cárdenas 1958; Cuéllar 1971; de Granda 1969; Phillips 1967), phonetic erosion (Cárdenas 1958; Méndez Pidal 1964; Widdison 1998), and interaction between phonetics and phonology (Bradley 1998, 1999, \& 2005).

According to Agüero (1962), Canfield (1962 \& 1981), Berk-Seligson (1984), Calvo Shadid \& Portilla Chaves (1998), Gaínza (1976), Lipski (1994), Umaña (1981), and Sánchez Corrales (1986), in the Spanish dialect spoken in the Central Valley of Costa Rica, which excludes dialects spoken in Guanacaste and on the Pacific coast, ${ }^{1}$ the enunciation of rhotics is quite different from that in neighboring countries. All these researchers argue that there is an assibilated rhotic that tends to replace the standard trill and which is highly characteristic of this Costa Rican dialect.

Studies by Calvo Shadid \& Portilla Chaves (1998) and by Sánchez Corrales (1986) describe the assibilated rhotic found in the Spanish dialect spoken in the Central Valley of Costa Rica (details are reported in section 2 below). These researchers propose that assibilation results from internal structural causes in which the trill undergoes pressure from the other fricative phonemes, resulting in an assibilated (fricated) rhotic.

This article thoroughly describes the phonetic realization and distribution of Costa Rican rhotics (the Standard trill as well as the tap). The hypothesis that underlies this study is that Costa Rican speakers native from the Central Valley region tend to produce an assibilated 
rhotic instead of the Standard trill in most contexts (based on previous reports by Calvo Shadid \& Portilla Chaves 1998; Chavarría 1951; Sánchez Corrales 1986, and Umaña 1981). The data on which the analysis is based were obtained through a reading task given to native speakers of the specific geographic area to elicit rhotics in various syllabic and grammatical positions. First, the article summarizes previous reports on assibilation in various Spanish dialects, followed by a report on previous studies on the assibilated rhotics found in the Costa Rican dialect from the Central Valley. The study compares the realization of rhotics in this Costa Rican dialect (based on the data) to those reported for other Spanish dialects. Finally, the article presents a possible account for the assibilation of rhotics in this dialect following the proposals by Bradley (1998; 2005), Cárdenas (1958), Widdison (1998), and Recasens (1991).

\section{Dialectal variation of Spanish rhotics}

A number of researchers have analyzed dialectal variation with regards to Spanish rhotics. Harris (1969), for example, identifies two phonetic realizations of the rhotics in a dialect spoken in Mexico City. Firstly, in what he calls nonenergic speech (i.e.; low volume) followed by a vowel either word-initially or between two vowels within a word (spelled with a double $\boldsymbol{r r}$ ), the trill ceases to be a trill and becomes "some sort of fricative" (46-47), which is voiced and quite strident, the tongue being slightly retroflexed (Harris represents it as [ź]). According to Harris, the same allophone is found in $s r$ clusters whether divided by a word boundary as in los ricos 'the rich' $(47)^{2}$ or within a word, as in Israel 'Israel'. Unfortunately however, Harris does not specify whether this fricated sound also surfaces after the consonant segments $/ 1 /$ and $/ \mathrm{n} /$ as does the trill in Standard Spanish (e.g., alrededor 'around', enredo 'mess/confusion'). Harris identifies a second variation of the trill ${ }^{3}$ in what he calls a "pre-pause but not pre-consonantal position," (47), namely a voiceless fricative, distinct from the alveolar because it is a voiceless apical given that it is retracted; he represents it as [ś]. This sound is found in words such as tomar 'to take' [tomaś], which contrasts with the minimal pair in the proper noun Tomás [tomás]. Overall, [ź] and [ś] are both strident and retracted, and the tongue is not high; they differ only in voicing, the former being voiced while the latter is voiceless. Harris ascribes the features [-anterior] and [-high] to the retracted allophones; he claims that [-high] is necessary to distinguish the two allophones from the alveopalatal sounds, while [-anterior] distinguishes them from the trill and tap. These two allophones of the trill are only found in casual speech, and they are what other researchers refer to as assibilated [ř $]$.

Bradley and Schmeiser (2002) report on the coarticulation of complex onset clusters in casual speech in some Spanish dialects. According to these researchers, whereas in Standard Spanish there is an intervening vowel segment in complex / $\mathrm{Cr} /$ onsets, which can have variable duration (e.g.; pronto $\left[\mathrm{p}^{\circ} \mathrm{r}\right]$ 'soon' and fresco [ $\left.\mathrm{f}^{\ominus} \mathrm{r}\right]$ ' $\mathrm{fresh}$ '), ${ }^{4}$ in some Peninsular Spanish varieties, as well as in contemporary American Spanish, this intervening vowel segment (known as a svarabhakti vowel) disappears and coarticulation of the two consonants occurs instead. That is to say, in casual speech, $/ \mathrm{Cr}$ / clusters are often heavily overlapped; this coarticulation causes some friction of the rhotic and the svarabhakti vowel is lost. In these dialects, rhotics are devoiced after voiceless consonants such as $/ \mathrm{k} /$, and dental $/ \mathrm{d}_{\mathrm{n}} /$ and $/ \mathrm{t}_{\mathrm{n}} /$ assimilate regressively to the rhotic, yielding an alveolar quasi-affricate realization such as [ $\left.\mathrm{t}_{\mathrm{o}}\right]$ (as opposed to $\left[\mathrm{t}^{\mathrm{D}} \mathrm{c}\right]$ in StandardSpanish). According to these two researchers, in Peninsular and Peruvian Spanish, coarticulation affects potentially any $/ \mathrm{Cr} /$ cluster in casual speech, whereas in other Latin American dialects, coarticulation is restricted to only clusters in which the first consonant is 
a coronal non-continuant. Stockwell and Bowen (1965) report this coarticulation phenomenon for parts of Chile and Perú. According to them, the tap becomes an approximant in tr- onset clusters, as in tres ('three'); this rhotic is similar to that found in English words such as dress, train, and run and which is not typical of the Spanish phonological inventory. Quilis (1999) also reports an affricated realization of rhotics in [tr] onsets in great part of Argentina, in Bolivia, some areas of the United States, in Guatemala, and in some parts of Spain, namely along the Ebro River, although unfortunately he does not provide specific details for the realization of this cluster in each of these regions. Quilis further states that affrication sometimes applies to the $[\mathrm{dr}]$ sequence, which is articulated as a sonorous post-alveolar affricated segment.

Bradley (2002) points out that in Standard Spanish /rC/ clusters where the rhotic is in coda position there is also evidence of a svarabhakti vowel segment that intervenes between the rhotic and the following consonant segment (e.g.; verdes [er $\left.{ }^{\curvearrowright} . ð\right]$ 'green.pl'). Based on spectrographic analyses, he claims that in Highland Ecuador this intervening vowel segment tends to disappear in casual speech; instead, an assibilated [̌r] surfaces before a homorganic consonant with the same voicing value, as in puerta [eř. .t] 'door', verde [eř.ð] 'green', and carne [ař.n] 'meat'. The assibilated segment normally devoices before [-voice] consonants, as illustrated in the first example. In any other context, that is, in coda position before heterorganic consonants as in cuerpo 'body' and garganta 'throat', /f/ surfaces instead; the svarabhakti vowel segment is very likely to surface, as well. Bradley emphasizes that assibilation in this context applies to casual speech only, although assibilation does not always occur; ${ }^{5}$ this is also the claim by Argüello (1978).

In a similar study, Bradley (1998) claims that in Ecuadorian Spanish assibilated [̌r] has replaced the Standard Spanish trill phoneme in the informal register. In fact, he argues that the Ecuadorian assibilated [ř $]$ patterns with Standard trill only in syllable-initial contexts. Both the assibilated [ $\breve{\mathrm{r}}]$ and the trill occur in word-initial position and in post-consonantal position, and they contrast with the tap intervocalically. According to Bradley however, in Ecuadorian Spanish the assibilated [ř can appear in several contexts the Standard Spanish trill cannot, and which can be summarized as follows:

1. [̌r] can appear in complex syllable onsets after coronal non-continuants, as in tres, vendrá, and saldrá ('three', $3^{\text {rd }}$ sg.will.come, ' $3{ }^{\text {rd }}$ sg.will leave'); the Standard Spanish trill can never appear as the second member of a complex onset (e.g.; *[tr]es, *ve[ndr]á).

2. The assibilated [ř can appear in word-internal coda position preceding a coronal with the same value for voicing, as in persona 'person' and puerta 'door'; [ř] is unattested in coda position before a following bilabial or velar. The Standard Spanish trill in contrast, can appear in coda position in emphatic speech, regardless of the following segment. Although normally a tap occurs word-finally, as pointed out in Bonet and Masacró (1997), the realization of coda rhotics shows a lot of variation across languages and dialects. ${ }^{6}$

3. Assibilated [ř] can appear word-finally in pre-vocalic position (e.g.; ir ahora 'to go now'), before a consonant (mayor gusto 'greatest pleasure'), and before a phrase boundary (la flor 'the flower'); the trill, in contrast, cannot appear word-finally before a vowel unless there is an intervening pause.

In this analysis, Bradley compares the distribution of assibilated [ř $]$ to that of the Standard Spanish trill. However, it is not clear why he analyzes the assibilated rhotic as a single underlying form in all phonological contexts. In Standard Spanish, the rhotic that underlies the environments outlined in 1, 2, and 3 above, for example, is a tap and not a trill. ${ }^{7}$ 
Bradley (2005) points out that in the Northern Peninsular Spanish dialect spoken in the Cantabrian province around Los Montes de Pas and Tudanca, the rhotic present in infinitival verb forms (e..g., comer die.INF, morir die.INF, lavar wash.INF) is lost before a consonant-initial clitic pronoun or before a definite determiners heading a noun phrase (e.g., medirlo 'measure.INF. ${ }^{\text {rd }}$ sg.it.MASC).

Assibilation of Spanish rhotics in Costa Rican Spanish was first reported in Chavarría Aguilar (1951). Umaña Aguilar (1981) also refers to the assibilation of rhotics in the Spanish spoken in the Costa Rican Central Valley. According to her report, the group /tr/ receives an alveolar articulation very similar to that in the post alveolar voiceless affricate in words such as ocho [očo] 'eight'; nonetheless, most Costa Ricans make and recognize the difference between otro 'another' and ocho. In addition, she posits that this particular $/ \mathrm{r} /$ is normally retroflex and closely resembles American English /tr/. /r/ also receives an assibilated retroflex pronunciation in syllable-final position, especially phrase-finally. Finally, the researcher states that the multiple $/ \mathrm{rr} /$ is enunciated as a grooved fricative [ž], which becomes retroflex in rapid speech.

Similarly, Sánchez Corrales (1986) points out that the assibilation of the trill in Costa Rican Spanish is a recent phenomenon. He describes two rhotics in this Spanish dialect, both of which are apico-alveolar fricatives and differ only in terms of voicing: $\left[\Lambda_{0}\right]$ and [\lrcorner$]$. According to the researcher, these two phonemes and the [s] phoneme, a post-dorsal voiceless fricative, share the same phonological environment, namely an intervocalic position $(\mathrm{V}-\mathrm{V})$; the voiceless rhotic, $\left[\Lambda_{0}\right]$ and the alveolar fricative [s], also appear after a vowel in word final position; V-\# (e.g.; almuerz' lunch' [al'mwe.. o], torció 'twisted' [to'ג jo], mar 'sea' ['mad ], pesos ['pesos] ). In a word such as conversar, pronounced [konbe'd。aı。] ('to talk') in this Spanish dialect, the assibilated rhotic appears both inter-vocalically and word finally. Here, Sánchez Corrales argues that the sequence [ıs] results in the deletion of the final phoneme because the two phonemes share the same phonological distribution; $[\mathrm{r}]$ assimilates to $[\mathrm{S}]$, resulting in the voiceless phoneme $\left[\Lambda_{0}\right]$.

Sánchez Corrales further proposes that the [ $\lrcorner]$ phoneme has two allophones, a fricative allophone and an affricate allophone. The fricative allophone always appears inter-vocalically or after [z] (e.g.; perro 'dog' ['peıo], amarra 'knot' [a'maıa], Israel [izıa'el]). The affricate allophone appears after a pause or after [n] or [l](e.g., rata 'rat' ['d $\mathrm{d}_{\mathcal{\lambda}}$ ata], reloj 'clock/watch'

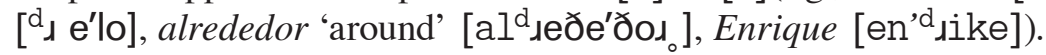

Similarly, Calvo Shadid and Portilla Chaves (1998) describe three assibilated retroflex variations of the rhotics found in the formal speech of four female informants in the San Jose area (i.e., the capital) of Costa Rica. In particular, they identified a voiced, retroflex, approximant [ $t$, a voiced retroflex fricative [z], and a voiced retroflex tap. They report that the retroflex allophones constituted $16 \%$ of the total number of rhotics identified (707), whereas the remaining $84 \%$ constituted alveolar rhotics. Inter-vocalically, $4 \%$ of the allophones of the tap were retroflex, whereas the retroflex allophones of the trill constituted the majority of the enunciations, namely $54 \% .^{8}$ The analysis revealed that retroflex allophones are found mainly in pre-consonant position. The retroflex allophone was not reported in consonant clusters. These researchers argue that in this Costa Rican dialect, there is a flap phoneme, which is mostly articulated at the alveolar ridge ( $96 \%$ of the time). Additionally, there is no trill; this phoneme has been substituted by a fricative phoneme represented as $/ \mathrm{s} /$.

Just as Sánchez Corrales (1986), Calvo Shadid and Portilla Chaves (1998) propose that this phoneme $(/ \mathrm{s} /)$ shares the same distinctive features as does /s/, except/s/is apical, as opposed to dorsal in the case of $/ \mathrm{s} /$; in other words, the first phoneme is [-anterior]. 
Similar to Sánchez Corrales (1986), the researchers propose that this similarity in terms of articulation between $/ \mathrm{s} /$ and $/ \mathrm{s} /$ is what causes the assibilated rhotic to emerge. In other words, this rhotic is a fricative sound just like /f/, /s/, and /x/; this structural pressure is what causes the rhotic to assibilate.

The current study adds a thorough analysis of all possible realizations of rhotics in data produced by Spanish-speakers native from the Central Valley in Costa Rica via an elicitation task. The study aimed to determining the environments in which an assibilated rhotic surfaces, and whether such segment is an allophone of the trill or an allophone of the tap. The phonetic realizations of rhotics in this dialect are compared to those previously reported for other Spanish dialects, and a possible account for the assibilation of rhotics in this Spanish dialect is also posited.

\section{The data}

The empirical basis for this study is a list of words and sentences in Spanish containing rhotics in all possible phonological environments; such environments were selected based on previous studies on Standard Spanish as well as on Latin American dialects (Bradley 1998 \& 2002; Bradley \& Schmeiser 2002; Harris 1969 \& 1983; Lipski 1994 \& 1990; Quilis 1999; Stockwell \& Bowen 1965). The task was designed to elicit five different phonological environments which would yield all possible realizations of either the trill or the tap (Refer to Appendix B for details on the distribution of the various phonological environments included in the task).

Six Costa Rican speakers native from the Central Valley and residing in San Ramón, a town of the province of Alajuela, were audio-recorded reading the list of words and sentences in the task. Four of the informants were teenagers (ranging from ages 12 to 19); two males and two females. The other two informants were a thirty-one-year-old female and a forty-six-yearold male. Each participant was instructed to read the list as informally as possible, trying to make use of their Costa Rican rhotics. ${ }^{9}$ The reason for this specification was the assumption that most Costa Ricans are able to speak with a Standard accent as they are constantly exposed to Standard Spanish. This is particularly true during formal tasks such as reading, as reported in Bradley (2002). All the recordings were transcribed by the author, a native Costa Rican, and the transcripts were then carefully analyzed in order to establish the distribution of each rhotic.

\section{Results: Analysis of Costa Rican rhotics}

\subsection{Standard trill $[\mathbf{r}]$ versus assibilated $[\check{r}]$}

The data revealed that all the participants substituted the trill with an assibilated $[\check{r}]$ in all contexts. This assibilated $[\check{\mathrm{r}}]$ is phonetically different from the Standard Spanish trill. Whereas the latter is generally described as a voiced alveolar trill (Kenstowicz 1994; Ladefoged 2001; Quilis 1999; Recasens 1991), the assibilated Costa Rican [ř ] is articulated by placing the tongue-tip behind the alveolar ridge (post-alveolar) and curling the tongue-tip up and back so that the underside approaches the alveolar ridge (retroflex); this sound is heavily fricated, which gives it its assibilated $[\check{r}]$ nature. 
This assibilated rhotic occurs in all contexts that the Standard trill occurs (i.e., in syllable-initial position). Specifically, [̌r] was found word-initially, as in (1a\&b) below, intervocalically (whenever the rhotic is spelled $\boldsymbol{r r}$ ), as in (1c\&d), and in post-consonantal position after $\boldsymbol{l}, \boldsymbol{n}$, and $\boldsymbol{s}$, as in (le,f\&g):
a) rico /ři.ko/
'delicious/rich'
b) ratón /řa.tón/
'mouse'
c) arroz /a.řós/
'rice'
d) carro /ka.řo/
'car'
e) Enrique /en.ři.ke/
'proper name'
f) alrededor /al.ře.de.dor/
'around'
g) Israel /is.řa.el/
'Israel'

This distribution can best be represented in terms of syllable structure, as shown in (2a-c) below. In all these contexts the rhotic is the sole onset consonant, followed by a vowel segment.
a. $\mathrm{V}_{\sigma}[-\mathrm{V}$
a.rroz
b. $\mathrm{VC}_{\sigma}[-\mathrm{V}$
En.ri.que
c. $\#[-\mathrm{V}$
ri.co

The analysis of the distribution of this assibilated $[\check{r}]$ in Costa Rican speech reveals a clear resemblance between the assibilated $[\check{r}]$ in Ecuadorian Spanish and that in Costa Rican Spanish (Bradley 1998). In both dialects the trill surfaces as [ř ] word-initially and post-consonantly, as well as intervocalically where it contrasts with the tap. This rhotic also has a similar distribution to the rhotic ascribed to the Mexican Spanish dialect examined in Harris (1969), although as pointed out earlier, it is unclear whether an assibilated [ř $]$ surfaces in contexts after $/ 1 /$ or $/ \mathrm{n} /$ in the dialect described by Harris, given that he does not specify.

In contrast to the Standard Spanish trill which in coda position can alternate with the tap in highly emphatic speech whenever it is followed by a consonant segment, (see examples $3 a, b$, and $c$ bellow taken from Bradley 1998: 59), the Costa Rican assibilated [ř ] never alternated with $[r]$ in emphatic speech. An alternation between the tap and an assibilated rhotic only occurred in coda position when the rhotic appeared phrase finally, as illustrated in examples $3 d \&$ e below; this alternation did not however indicate emphasis. Instead, in order to indicate emphasis, the speakers tended to lengthen the vowel that preceded the rhotic; in such case, the tap / [̌r] alternation did not occur.
(3) a) mayor gusto
$\operatorname{mayo}[\Gamma-\check{r}]$ 'greatest pleasure'
b) la flor
flo[r-řr $]$ 'the flower'
c) cuerpo
cue [r- ř $]$ po 'body'
d) vamos a comer pizza
come $[\mathrm{r}] / *[\check{\mathrm{r}}]$ 'let's go eat pizza'
e) vamos a comer
$\operatorname{com}[\mathrm{er}] /[\mathrm{er}]$ 'let's go eat' 


\subsection{The alveolar tap $[\mathrm{r}]$}

The analysis additionally reveled that the voiced alveolar tap found in Costa Rican Spanish appears word-medially and word-finally, never word-initially; this is the same pattern found in Standard Spanish. Specifically, $[r]$ appears between two vowels (spelled as a single $-\boldsymbol{r}$, where it contrasts with the trill), 2) after consonants other than $l, n$, and $s$, before any consonants, and word finally, as shown in the examples in 4 below:

(4)
a) flora [flora]
'flora'
b) $\operatorname{caro}[\mathrm{karo}]$
'expensive'
c) abridor [aßridor] 'can opener'
d) grito [grito]
'scream'
e) tres [tres]
'three'
f) larga [larga]
'long.fem'
g) comer [komer]
'to eat'

In terms of syllable structure, the tap appears in three phonological environments: 1) in onset position (word-medially), as in examples $4 \mathrm{a} \& \mathrm{~b}, 2$ ) as the second element of a complex syllabic onset cluster, as in examples $4 \mathrm{c}-\mathrm{e}$, and $3 \mathrm{ab}$ ), and in a coda (syllable finally), as in examples $3 \mathrm{f} \& \mathrm{~g}$. These environments can be represented as follows:
a. $\mathrm{V}]_{\sigma}-\mathrm{V}$
$(4 \mathrm{a} \& \mathrm{~b})$
b. $\sigma[\mathrm{C}-\mathrm{V}]$
$(4 \mathrm{c}-\mathrm{e})$
c. $\left[\mathrm{V}-{ }_{\sigma}\right]$
$(4 \mathrm{f} \& \mathrm{~g})$

In contrast to Standard Spanish where the tap normally does not undergo any assimilation, in this Costa Rican dialect $[r]$ assimilated in three different contexts.

1. The first assimilation process of the tap occurs after the coronal non-continuant voiceless phoneme [t], where /s/ became voiceless and assibilated in any context (i.e.; wordinitially and word-medially); some examples are,

(6)
a) atrás /atr̆ as/
'behind'
b) trato / $/ \mathrm{rr}_{\circ}{ }^{\circ}$ ato/
'deal'
c) tres $/ \mathrm{tr}_{0}^{2} \mathrm{es} /$
'three'
d) cuatro /cuatr ${ }_{\circ}^{\sim} \mathrm{O} / \quad$ 'four'

Several phonetic processes are responsible for this assibilation and devoicing. Firstly, the voicelessness of the preceding coronal non-continuant [t] causes devoicing of the rhotic (i.e., $\left./ \mathrm{f} / \rightarrow\left[\mathrm{r}_{\mathrm{o}}\right] /[\mathrm{t}]_{-}\right)$. This voicing assimilation process in turn causes the resulting rhotic to be assibilated (i.e.; $/ r_{0} / \rightarrow\left[\check{r}_{0}\right]$ ). Furthermore, the two consonant segments, namely $[t]$ and $[r]$ undergo coarticulation; that is, the /tr/ cluster is heavily overlapped, as there is some friction of the rhotic. Coarticulation is also responsible for assibilation, as it yields an affricated 
sound. In addition, the coronal phoneme /t/ undergoes regressive assimilation as well, because its place of articulation shifts slightly back to the post-coronal region. Based on their study on Ecuadorian rhotics, Bradley (1999) and Bradley and Schmeiser (2002) point out that the overlap between the tongue tip gesture of $[r]$ and the glottal spreading feature of $[t]$ result in partial devoicing of the rhotic segment; this is exactly what was evidenced in the speech of the sample. In sum, the devoicing and assibilation processes that occur in $t r$ clusters is a result from gestural overlap; it is a phonetic process.

This particular $t r$ cluster is what other studies have referred to as an alveolar affricate or quasi-affricate, very similar to that in the Spanish word ocho [otfo] 'eight' (Bradley \& Schmeiser 2002; Lipski 1994; Stockwell \& Bowen 1965). An assibilated pronunciation of $t r$ clusters has also been attested in parts of Argentina, Chile, Highland Perú, Highland Ecuador, the United States, Spain, and Guatemala (Quilis 1999). Bradley and Schmeiser (2002) propose that the articulation of this tr cluster closely resembles that of English words such as 'tree', and 'train'; Stockwell \& Bowen (1965) and Lipski (1994) also agree with this comparison with English.

The intervening vocalic segment that emerges between the consonant and the rhotic in tr clusters in Standard Spanish was not evidenced in this Costa Rican dialect. As pointed out in Bradley (1999) when he describes this coarticulation phenomenon in Ecuadorian Spanish, when the tongue tip gesture for the tap and the following homorganic consonant are overlapped, no svarabhatki fragment can be recovered. According to Bradley (1999), the gestural overlap between a coda tap and a following coronal is due to the fact that both consonant gestures involve the same articulator.

2. The second context where [r] undergoes assimilation is in word-medial complex $d r$ onset clusters that come after a voiced sonorant coronal $(l$ or $n)$. Here, the tap is realized as an assibilated [ř $]$. This assibilation results from a process of coarticulation whereby the segment intervening between the voiced sonorant coronal and the rhotic, namely /d/ heavily overlaps with the rhotic, yielding a fricated sound $[\check{r}] .{ }^{10}$ As with $t r$ clusters, the gestural overlap between a tap in onset clusters and a following coronal /d/ results from the fact that they involve the same articulator; nonetheless assibilation only applies in contexts where the $d r$ cluster is preceded by a voiced sonorant consonant segment $l$ or $n$. In the dialect analyzed here, /d/ undergoes place assimilation as well, as the tongue tip shifts back toward the post-alveolar region. Some examples where this assibilated $[\check{\mathrm{r}}]$ is realized include:
a) vendrá
[bendřá]
'come.future. $3^{\text {rd }} . \mathrm{sg}$ '
b) saldrá
[saldřá]
'leave.future. $3^{\text {rd }} . \mathrm{sg}$ '
c) pondría [pondřía]
'put.future.cond. $3^{\text {rd }} . \mathrm{sg}$ '
d) pondrá
[pondřá]
'come.future. $3^{\text {rd }} . \mathrm{sg}$ '
e) Andrea
[andřéa]
'proper name'
f) Andrés
[andřés]
'proper name'
g) Alexandra
[aleksándřa]
'proper name'
h) podrá
*[podřá]
'be.able.to.future. $3^{\text {rd }} . \mathrm{sg}$ '
i) esdrújula
*[esdřúhula]
'word stressed on untepenultimate syllable' 
In $7 \mathrm{~h} \& \mathrm{i}$, this assibilation rule does not apply because the complex onset in the second syllable does come after a voiced sonorant coronal (indicated in bold in examples 7a-g).

In order to account for the coarticulation in [dr] clusters, I turn to Ohala's (1995) notion of emergent stops. According to this researcher, it is very likely for a stop to emerge between a nasal or a lateral and an oral consonant such as the tap. Ohala (1995) states that crosslinguistically, it is very common to find a stop consonant emerging between a nasal consonant and an oral consonant (55) due to the articulation process involved. Ohala points out that a nasal consonant is produced by exhaling air through the nasal cavity, which entails a closure in the oral cavity and an opening of the nasal cavity by lowering of the soft palate (55). He further indicates that in the production of any oral consonant, there is closure of the nasal valve by elevating the soft palate; if the soft palate closure is made prematurely during the last portion of the nasal that precedes the oral consonant; and taken that both the oral and nasal valves are closed, a complete stoppage of air flow is produced and a stop consonant then emerges between the nasal and the oral consonant. This phenomenon is what appears to be taking place in this data in contexts where a nasal or a lateral consonant precedes a rhotic segment; in the transition between $n$ and the rhotic or $l$ and the rhotic, both air passages may be briefly closed, thus forming an intervening stop, namely /d/. In examples 7 h\&i above, assibilation does not apply because there is no emergent stop consonant.

But why postulate that $/ \mathrm{d} /$ constitutes an intervening stop segment and not part of the Spanish morphology? A /d/ segment normally appears between a voiced sonorant coronal and a rhotic at the boundary between a morpheme and the future tense affix - $d r$. If we examine the Spanish morphology for future tense formation, it is clear that $-r$ and not $-d r$ normally marks future tense, as can be seen in the examples in 8 below:

(8) infinitive form $\rightarrow$ future form
a) une
$\rightarrow \quad$ unirá, not *unidrá
'will.connect. $3^{\text {rd }} . \mathrm{sg}$ '
b) come
$\rightarrow$
comerá, not *comedrá
'will.eat. ${ }^{\text {rd }}$.sg.'
c) comprar
comprará, not *compradrá
'will.buy. $3^{\text {rd }} . \mathrm{sg}$ '

In fact, only a small number of irregular verbs insert a consonant - $d$ to indicate future, namely those where the future marker $-r$ (i.e.; the rhotic phoneme) is preceded by a voiced sonorant coronal. The stop consonant $/ \mathrm{d} /$ emerges due to a phonetic process, and it is not part of the Spanish morphology. ${ }^{11}$ It is hence not surprising that this segment tends to be coarticulated with its following consonant segment, namely the rhotic.

With regards to the proper names where the same phenomenon applies (i.e.; a consonant stop emerges between $n$ or $l$ and a rhotic), one might expect coarticulation and hence assibilation of the rhotic to occur. However, the data indicate that Costa Rican speakers tend to avoid coarticulation of the /dr/ cluster in proper names. In fact, only a single subject in this study coarticulated the $[\mathrm{dr}]$ cluster in more than one proper name ${ }^{12}$ whereas all six participants did so in the verbs containing the same consonant cluster. By and large, the native Costa Rican speakers included in this study avoided coarticulation in proper names as well as in foreign names. This most likely reflects code-mixing (i.e.; speakers mix between the Standard and regional dialects). 
Bradley (1998) talks about assibilation in complex onsets in Ecuadorian Spanish. Nonetheless, he does not specify whether such assibilation might also take place in words such as those in $7 h \& i$. If the reasoning provided here for this assimilation process should hold, one would expect that Ecuadorian Spanish would not allow assibilated [̌r] to surface in environments like $7 h \& i$ either.

Overall, the data revealed an assibilated rhotic in complex onsets, which appeared to result from coarticulation of a coronal segment and a following rhotic. This is the same phenomenon evidenced in Peninsular Spanish (Quilis 1999; Stockwell \& Bowen 1965), parts of Chile, Perú, Argentina, Bolivia, Guatemala, and the United States (Quilis 1999; Stockwell \& Bowen 1965), and in Highland Ecuador (Bradley 1998).

Finally, in /rC/ clusters, where in Standard Spanish there is normally an intervening svarabhatki vowel segment that surfaces between the consonant and the rhotic, the data analyzed did not evidence this segment, even in cases where no coarticulation took place. Similarly, while Highland Ecuador has an assibilated rhotic in /rC/ clusters (Bradley 2002), this Costa Rican Spanish only allows a tap.

3. Based on the observations of the subjects' natural speech as well as on consultations with native Costa Ricans, a singular phonetic process applies to taps in $/ \mathrm{rC}$ / clusters whenever the tap is in coda position followed by a syllable that constitutes a consonant-initial clitic. In such cases, many speakers tend to delete the rhotic altogether in informal speech, as the examples in 9 illustrate:
a) ponerle [ponéle]
'to.put.[something]on.it'
b) comerlo [komélo]
'to.eat.it'
d) saberlo [sabélo]
'to.know.it'
e) tomárselo [tomáselo]
'to intake something'

In word-internal - $r$ - clusters, this deletion rule never applies, as shown in the two examples below:
a) parlamento [parlaménto]
'parliament'
b) charlatán [t farlatán]
'joker'.

Examples such as $10 \mathrm{a} \& \mathrm{~b}$ suggest that this deletion process only applies at a morpheme boundary, namely, when the rhotic is preceded by one or more consonant-initial clitic pronouns. This phenomenon is also reported for Cantabrian Spanish (Bradley 2005). Nonetheless, Bradley also reports that this deletion of the rhotic segment also occurs before determiners, which was not evidenced in the Costa Rican dialect analyzed here.

An additional context where the tap emerged as an assibilated rhotic according to the data was phrase-finally. Phrase-finally, /f/ devoices, and hence assibilates, as shown in the examples in (11). This assibilation of the tap cannot take place phrase-medially, as shown in 11c:
a) vamos a comer [bamosakomer ${ }^{`}$ ]
'let's eat'
b) es hora de dormir [esoradedormir ${ }^{\circ}$ ]
'it's time to sleep'
c) vamos a comer pizza *[bamosakomer ${ }_{\circ}^{2}$ pitsa]
'let's eat pizza' 
Final devoicing is very common crosslinguistically; according to Kenztowicz (1994) and Quillis (1999), phrase-final lengthening is probably universal. In the case of the Spanish dialect analyzed here, it is very likely that the tap gesture gets quite long, resulting in assibilation; assibilation could not apply word-medially in such contexts because final lengthening does not apply.

\section{Possible accounts for assibilation}

Although according to Widdison (1998) and Quilis (1999) the most common reason ascribed to assibilation of Spanish rhotics has centered on the influence from other language systems such as Basque, English, and Native American languages, this explanation is rather inaccurate. As an example, Widdison points out that the geographic spread of the assibilation phenomenon does not necessarily match the historical settlement patterns of the various geographic groups; "in those areas where the adstrat influence was greatest, phonetic variation of the trill is minimal and vice-versa" (53).

Similarly, Calvo Shadid and Portilla Chaves (1998) argue that the proposal that the retroflex assibilated rhotic in Costa Rican Spanish originates due to influence from English is not well founded, given that only one of the three retroflex rhotics found in the study by Calvo Shadid and Portilla Chaves exist in English, namely the approximant retroflex. Furthermore, the number of English-Spanish bilingual speakers in the Central Valley in Costa Rica is extremely small, and in other Latin American countries where there is a significant influence of the English language, no instances of retroflection of rhotics have been reported (as in the case of Puerto Rico). Finally, Calvo Shadid and Portilla Chaves argue that many of the Costa Rican speakers who produce the retroflex rhotics are farmers, with little formal education (i.e., the chance of having influence from the English language is slight).

A more suitable account of dialectal variation (i.e.; an explanation that affects the entire Spanish system despite specific geographic location) for explaining the weakening of Spanish rhotics, has to do with changes in the place, manner, and voicing of the rhotics, in particular the trill, that arise from natural physiological limitations in producing the complex event that characterizes the trill.

For instance, Malmberg (1950) (cited in Widdison 1998) claimed that assibilation of the trill followed the historical pattern of Spanish to convert the Latin simple-geminate distinction into one of quality; this change was already realized on nasal and lateral sounds (Widdison: 53). The same claim was made by Cárdenas (1958) who points out that since in Romance Castilian the geminates /nn/ and /11/ got palatalized (i.e.; / $/ \mathrm{n} /$ and $/ \mathrm{K} /$ respectively), the trill tends to become a continuant assibilated segment as a result of economy.

Widdison (1998) also alludes to phonological weakening when he adopts Recasens's (1991) statement that in order to avoid the complexity in enunciating a trill, an effective strategy in reducing tension in the tongue tip can be obtained by "simultaneously elevating and retracting the postdorsum of the tongue towards the soft palate while maintaining the alveolar constricted, creating a slight hollowing in the tongue body" (Recasens, 1991: 278). Widdison further points out that the trill is highly resistant to coarticulation due to the great production constraints that it entails; the same factors that make the trill highly resistant to coarticulatory effects however seem to "create inherent instability in the trill itself" (55). Widdison claims that a slight change in any of the three main parameters that involve the production of a trill, namely airflow, resistance, and body tension and position, will lead to significant alteration 
in the quality of the sound produced; this is responsible for the large variation observed in Spanish trill. Widdison even argues that, "the complexity of the alveolar trill accounts for its relative obscurity in language systems much like other exotic sounds such as clicks: while neither type of phone is difficult to produce in isolation, both present formidable challenges when integrated into the suboptimal conditions under which running speech operates" (Widdison 1998: 58).

Bradley (1998 \& 2005) takes a similar approach when he proposes an interaction of phonetics and phonology by adopting the assumption that, "categorical features of the phonological representation are mapped on to gestures, which define quantitative articulatory movements" (Bradley 1998: 64). In concrete, with regard to syllable-initial assibilated [ř], Bradley (1998) postulates a phonetic implementation of the trill, which yields a tongue tip gesture of reduced magnitude. While the Standard trill requires a tensed and controlled tongue tip gesture in order to initiate sustainable vibration as a result of the air pressure, assibilated $[\check{r}]$ requires a reduced magnitude of the tongue-tip gesture, which precludes vibration and yields a sustainable turbulent airflow.

Additionally, according to Bradley (1998), in Ecuadorian Spanish a tap in complex onsets surfaces as an assibilated [̌r] when /r/ is overlapped by an adjacent tongue-tip gesture. As a result, the duration of the tap then increases; fricatives are longer than taps in order to allow pressure to build up at the place of contriction.

In order to account for why in the Costa Rican Spanish data analyzed word-final taps only undergo assibilation phrase-finally, I allude to final devoicing which, according to Bradley (1998) and Kenstowicz (1994), is a very common phenomenon crosslinguistically.

Overall, variation in the production of the trill appears to result from natural physiological processes, namely from articulatory weakening. The tap undergoes assibilation in complex / $\mathrm{tr} /$ onsets due to coarticulation of the two segments. A physiological account for assibilation of rhotics seems suitable because, as Widdison (1998) points out, it is very likely that "the causal forces motivating the pattern [that of assibilation] likely represent general phonetic tendencies constraining all language systems" (54). The fact that a phenomenon such as assibilation gets carried out completely in some languages, partly in others, and not at all in others, might be a function of the sociolinguistic variables that moderate the transmission of novel forms, as Widdison further states.

\section{Concluding Remarks}

The analysis provided here evidences that the data collected in the Costa Rican Central Valley revealed a substitution of the Standard trill with an assibilated [řr] in all contexts. The tap found in this dialect undergoes assimilation in three different contexts as compared to the Standard Spanish tap, which does not. The tap gets assibilated and devoiced in complex /tr/ onset clusters. It also assibilates word-medially in complex onsets that come after a voiced coronal $/ 1 /$ or $/ \mathrm{n} /$. I postulated that in these contexts, the $/ \mathrm{d} /$ segment which intervenes between the coronal stop and the rhotic tends to assibilate because it is an emergent stop; this was concluded based on the fact that only a few words contain a $-d r$ morpheme to mark the future tense. This emergent stop /d/ gets coarticulated, resulting in the voiceless assibilated rhotic. This emergent stop also emerges in proper names as well as in foreign words where a nasal or lateral coronal precedes a rhotic, and hence the resulting segment is also an assibilated rhotic. In addition, a deletion rule applies to the tap in $/ \mathrm{rC} /$ clusters where the rhotic is in coda position; in such contexts, the tap gets deleted altogether. 
A final context where assibilation applies in this dialect is phrase-finally. This was explained as a common coosslinguistic phenomenon, namely that of phrase-final devoicing. The fact that assibilation does not apply phase-medially was explained in terms of resyllabification, a post-lexical phenomenon.

Assibilation of trills in this dialect was accounted for in terms of natural physiological limitations in producing the complex trill. The tap, conversely, gets assibilated as a result of coarticulation, as the duration of the tap increases yielding a fricative segment. Weakening of rhotics was explained in these terms because physiological limitations apply to general phonetic tendencies in all language systems.

Future research in first language acquisition in this Spanish dialect would support the claim that assibilation of rhotics results from an economy principle, a cross-linguistic tendency. I am currently investigating whether children native from the Costa Rican Central Valley start producing an assibilated rhotic before they are able to produce the trill; this would suggest that indeed, assibilation is an alternative, less complex way of enunciating the trill. Such a finding would further constitute positive news for non-native speakers attempting to acquire Spanish as a second language, as they could resort to an assibilated rhotic in substitution of the often times frustrating trill.

\section{Notes}

1. See Appendix A for a map adapted from Canfield (1981) with the distribution of asibilated -r throughout Costa Rica.

2. Notice that in los ricos, a fricated rhotic would be expected not necessarily because it is in a $s r$ cluster as stated in Harris, but because it consists of an initial rhotic followed by a vowel, namely $-i$.

3. Harris describes this rhotic as an allophone of the trill, not the tap, as is claimed for word-final rhotics in Standard Spanish.

4. According to Quilis, 1999, the presence of this intervening vocalic segment was first put forth in Lenz (1892), who identified it in parts of Chile.

5. In his study, Bradley found variability in the assibilation of rhotics in $/ \mathrm{rC} /$ contexts. He warns that in a formal task like the one he used, namely reading, there is a tendency to produce careful speech.

6. Bonet and Masacró (1997) propose that at the output of lexical phonology, all dialects have a tap, and tensing and other phenomena result from late post-lexical rules.

7. Despite the fact that this assibilated rhotic is phonetically realized the same in various contexts, it may not be the case that it constitutes a single UR. In fact, in the analysis of the assibilated Costa Rican rhotics presented in section 4.2 , the suggestion is that the assibilated [ř $]$ that is realized in contexts 1-3 above is an allophone of the tap and not the same phoneme as the one that has substituted the Standard Spanish trill.

8. According to Calvo Shadid and Portilla Chaves (1998), no instances of the trill were identified in their sample. Previous studies also report low percentages of the use of the trill (2 to 3\%) in this Spanish dialect (e.g., Umaña 1981). 
9. The decision to specify the register to be used in the task was based on the claims in Cárdenas (1958), Berk-Seligson (1984), and (Lipski 1990) that the assibilated rhotic, which Costa Ricans from the Central Valley are typically identified by (Lipski 1990), might be rather stigmatized. It was predicted that most participants might make an effort to produce a Standard pronunciation, in particular with regards to the rhotics, in an effort to be identified as belonging to a prestigious social group; this would not have allowed for an accurate analysis of the rhotics that have been claimed to characterize this specific Spanish dialect (Lipski 1990, Widdison 1998).

10. The possibility of coarticulation in /dr/ clusters is predicted in Quillis (1999).

11. A different possibility might be that the insertion of the /d/ segment which resulted from phonetic implementation has since been incorporated into the Spanish morphology and it retains a strong overlap.

12. As a way to confirm this hypothesis, other Spanish words that contained a nasal or a lateral followed by a $[\mathrm{dr}]$ cluster were examined. Indeed, most of the words containing a $n d r / l d r$ cluster consist of proper names such as Alondra and Mildred. All other words of this type are foreign, as in androide 'android', Sal Andrews, and calandria 'lark' (i.e.; they are borrowings). Upon asking native Costa Rican speakers, it was confirmed that in fact, they normally avoid coarticulation of -drclusters in proper names and foreign words.

\section{References}

Agüero, A. 1962. El español de América y Costa Rica. 2n ed. San José: Lehman.

Argüello, F. 1978. The žeista dialect of Spanish spoken in Ecuador: A phonetic and phonological study. Ph.D. dissertation, Pennsylvania State University.

Berk-Seligson, S. 1984. Subject reactions to phonological varation in Costa Rican Spanish. Journal of Psycholinguistic Research. 13: 415- 442.

Bonnet, E. \& J. Mascaró. 1997. On the representation of contrasting rhotics. In: A. MoralesFront and F. Martínez-Gil (eds.). Issues in phonology and morphology of the major Iberian languages, 103-126. Washington D.C.: Georgetown University Press.

Bradley, T.G. 1998. Assibilation in Ecuadorian Spanish. In J.M. Authier, B.E. Bullock, and L.A. Reed (eds.) Formal Perspectives on Romance Linguistics. Selected papers from the $28^{\text {th }}$ Linguistic Symposium on Romance Languages, April, 1998, 57- 71.

1999. Assibilation in Ecuadorian Spanish: A phonology-phonetics account. Formal Perspectives on Romance Linguistics. J. M. Authier, B.E. Bullock, and L. A. Reed (Eds.), 57-71. Amsterdam: John Benjamins.

2002. (To appear). Gestural timing and rhotic variation in Spanish Codas. Laboratory Approaches to Spanish Phonology, ed. by Timothy Face. Berlin: Mouton de Gruyter. 
2005. Systemic markedness and phonetic detail in phonology. In Experimental an theoretical approaches to romance linguistics, ed. By Randal Gess and ed Rubin, 41-62. Amsterdam: John Benjamins.

Bradley, T.G. \& B. Schmeiser. 2001. On the phonetic reality of Spanish /I/ in complex onsets. University of California: Working draft.

Browman C. \& L. Goldstein. 1986. Towards and articulatory phonology. Phonology Yearbook. 3: $219-252$.

Calvo Shadid, A. \& M. Portilla Chaves. 1998. Variantes retroflejas de / $/ \mathrm{y} / \mathrm{r} /$ en el habla culta de San José. Revista Káñina. 22 (1): 81- 86.

Canfield, D. L. 1962. La Pronunciación del Español en América. Bogotá: Grupo Caro y Cuervo XVII.

1981. Spanish pronunciation in the Americas. Chicago: The University of Chicago Press.

Cárdenas, D. 1958. The geographic distribution of assibilated R and RR in Spanish America. Orbis. 7: 407- 410.

Chavarría Aguilar, O. 1951. The phonemes of Costa Rican Spanish. Language. 27: 248- 253.

Cotton, E. \& J. Sharp. 1988. Spanish in the Americas. Washington D.C. George University Press.

Cuéllar, B. 1971. Observaciones sobre la "RR" velar y "Y" africada en Cuba. Español Actual. 20: $18-20$.

Gaínza, G. 1976. El español de Costa Rica: Breve consideración acerca de su estudio. Revista de Filología y Lingüística. 11 (4): 79- 84.

Harris, J.W. 1969. Spanish Phonology. Cambridge, Massachusetts: MIT Press.

1983. Syllable structure and stress in Spanish. Cambridge, Massachusetts: MIT Press.

Jiménez, B. 1967. Acquisition of Spanish consonants in children aged 3-5;7 months. Language and speech Hearing Service Schools. 18: 357- 363.

Kenstowicz, M. 1994. Phonology in generative grammar. Cambridge, MA: Blackwell Publishers.

Ladefoged, P. 2001. A course in phonetics. University of California, Los Angeles: Harcourt College Publishers. 
Lipski, J.M. 1994. Latin American Spanish. New York: Longman.

1990. Spanish taps and trills: Phonological structure of an isolated opposition. Folia Lingüística. 29: 153- 174.

Menéndez Pidal, R. 1964. Orígenes del español. 5th ed. Madrid, España: Espasa-Calpe.

Navarro, T. 1974. El español de Puerto Rico. Universidad de Puerto Rico: Editorial Universitaria.

Núñez, R. 1980. La fonología moderna y el español de Santo Domingo. Santo Domingo, República Dominicana: Editora Taller.

Ohalla, J.J. 1995. Phonetic explanantions for sound patterns: Implications for grammars of competence. University of California, Berkeley.

Phillips R. 1967. Los Angeles Spanish: A descriptive análisis. Unpublished Doctoral Dissertation, University of Wisconsin.

Quilis, A. 1999. Tratado de fonología y fonética españolas. Madrid: Editorial Gredos.

Recasens, D. 1991. On the production characteristics of apicoalveolar taps and trills. Journal of phonetics. 19: 267- 280.

Sánchez Corrales, V. 1986. Escisión fonológica de /I/en el español de Costa Rica. Revista de Filología y Lingüística. 12 (2): 129- 133.

Stockwel, R.P. \& Bowen, J.D. 1965. The sounds of English and Spanish. Chicago: The University of Chicago Press.

Umaña Aguilar, J. 1981. Variable vibrants in middle-class Costa Rican Spanish. Unpublished Masters Thesis, Georgetown University.

Widdison, K. 1998. Phonetic motivation in Spanish trills. Orbis: bulletin international de documentation linguistique. 140: 51- 61. 


\section{Appendix A}

Costa Rican map: the horizontal lines represent the geographic regions that speak the dialect analyzed in this paper.

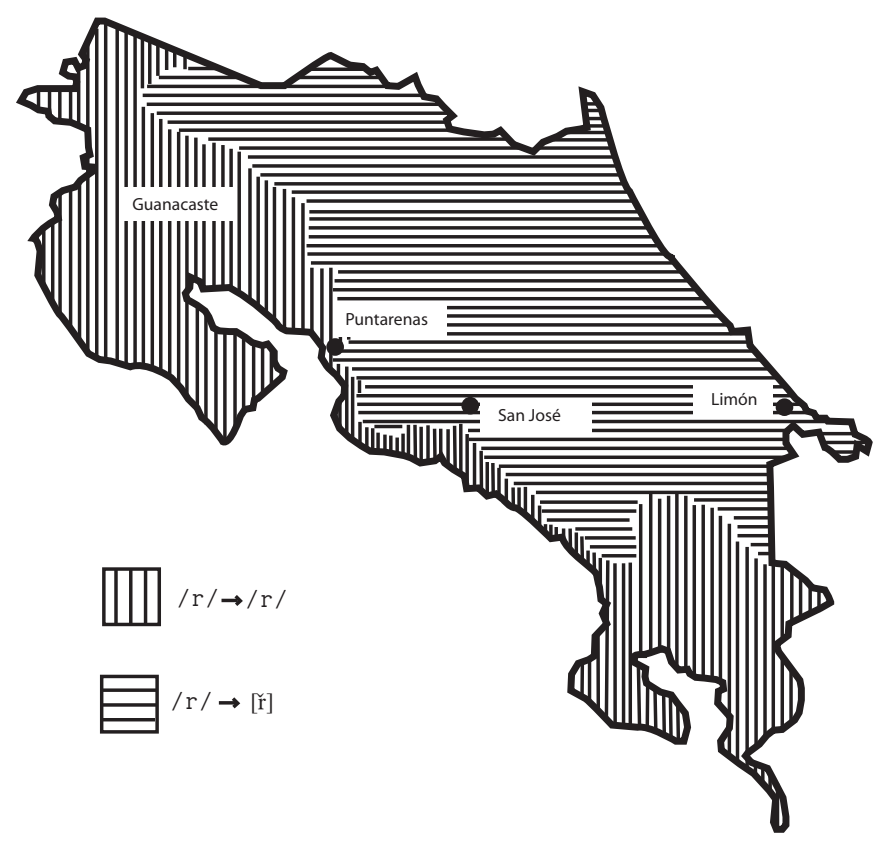

Adapted from Canfield (1981: 41).

\section{Appendix B}

Details on the distribution of the phonological environments included in the task:

Word-initial rhotics ([\# .-v]): 19\% of all words in the test that contained rhotics consisted of a word-initial rhotic followed by a vowel, as in rico 'rich / delicious', reloj 'watch', and Ronald 'proper name'. The goal here was to determine whether the participants produced a Standard trill or an assibilated rhotic instead. Words containing initial rhotics were elicited either at the beginning (single words), in the middle, or at the end of a grammatical sentence in order to look at possible variation based on the position of the word within the phrase.

1. Intervocalic rhotics $([\mathrm{v}-\mathrm{v}])$ : applied in order to assess the contrastive realization of single ' $r$ ' and double ' $r r$ ' intervocalically. $31 \%$ of the words in the test consisted of an intervocalic rhotic; the words included multiple minimal pairs such as caro 'expensive', and carro 'car'.

2. Complex syllable onsets ([C-]): $33 \%$ of the words in the test consisted of a labial, coronal, or dorsal consonant segment followed by a rhotic, as in alrededor 'around', tren 'train', dragón 'dragon', and agricultura 'agriculture'. These words were designed 
to elicit possible instances of assimilation resulting from the type of consonant preceding the rhotic, possible coarticulation of the rhotic and its preceding consonant, and the presence or absence of a svarabhakti vowel.

3. Word-internal coda rhotic ([-.C]): $11 \%$ of the words in the test consisted of a rhotic followed by a consonant sound, as in ardor 'burning', dormir 'to sleep', hervir 'to boil', parlamento 'parliament', urge 'it is urgent'). All possible $[\mathrm{rC}]$ contexts were analyzed (i.e.; labial, coronal, and dorsal) in order to look at probable variation resulting from the consonant following the rhotic. These words were also examined for possible svarabhakti, as well as for the possibility of coarticulation of the rhotic and its following consonant segment.

4. Word-final rhotics ([v-\#]): $19 \%$ of the words in the test contained a rhotic as the final segment (i.e.; in coda position). These words were elicited either at the beginning (single words), in the middle, or at the end of a grammatical sentence in order to look at possible variation based on the position of the word within the phrase. 
